\title{
Federalism, Decentralization, and Health Care Policy Reform in India
}

\author{
Divya H. Pahwa ${ }^{1} \&$ Daniel Beland ${ }^{2}$ \\ ${ }^{1}$ Department of Sociology, McGill University, Montreal, Quebec, Canada \\ 2 Johnson-Shoyama Graduate School of Public Policy, University of Saskatchewan campus, Saskatoon, \\ Saskatchewan, Canada \\ Correspondence: Daniel Beland, Johnson-Shoyama Graduate School of Public Policy, University of \\ Saskatchewan campus, Saskatoon, Saskatchewan, Canada, S7N 5B8. Tel: 1-306-966-1272. E-mail: \\ daniel.beland@usask.ca
}

Received: January 18, 2013 Accepted: February 20, 2013 Online Published: April 24, 2013

doi:10.5539/par.v2n1p1 URL: http://dx.doi.org/10.5539/par.v2n1p1

\begin{abstract}
This article explores how the Indian federal structure impacts health care. India has a history of central planning and concentration of power at the federal level. This concentration of power has left state and local levels of government in a subordinate position. Such a situation has distorted incentives, and a by-product of this has been a rather disorganized health care system. Disorganization and fiscal limitations have become major obstacles to large-scale reform of India's health care system. However, reform is necessary. As argued, a stronger, more decentralized, and better regulated public health care system should improve human welfare in India, while fostering the development of a stronger sense of national identity derived from shared, universal social citizenship.
\end{abstract}

Keywords: India, health care, policy reform, federalism, decentralization, citizenship, national identity

\section{Introduction}

In recent years, a growing number of scholars have explored the relationship between federalism, decentralization, and social policy, including health care (e.g., Noël, 1999; Obinger et al., 2005; Théret, 1999). More specifically, single-country and comparative studies have considered the federalism-health care nexus (e.g., Banting and Corbett, 2002; Holahan et al., 2003; Maioni, 1998; Weissert and Scheller, 2008). In this article, we explore how the Indian federal structure impacts health care policy in such a large, diverse, and fragmented country. The Indian federal structure has been shaped by a history of central planning and concentration of power at the federal level. This concentration of power has left state and local levels of government in a subordinate position (Bagchi, 2003: 21). This subordination has created distorted incentives within the political institutions of India. Local level governments are unable to wield the power necessary to properly execute region-specific policies. A by-product of this has been a disorganized health care system. This disorganization materializes, for example, in the form of mismatched funding to state and local governments, or of a concentration of health care professionals in urban areas. Reform to the Indian health care system is necessary. As argued in this article, one of the most effective ways to strengthen citizenship and national unity is to ensure that the health care needs of those living in rural areas are being met. Ensuring rural health care needs would show that the Indian government cares about the welfare of its entire people, and not only urban dwellers. In turn, this would help create a sense of universal social citizenship in India (Note 1). We are aware that these policy suggestions do not inclusively address all the issues and difficulties present in the current Indian health care system. The suggestions offered are argued to be an initial step to greater reform.

In order to analyze health care reform and its potential consequences for citizenship and national unity, we must examine how India's federal institutions shape the country's health care system and, in particular, its connection with rural citizens. This analysis features a look at the territorial and institutional organization of health services in India in order to address the following questions: how does Indian federalism impact the health care system and, in the end, can this system offer "comparable levels of health services" (Banting and Corbett, 2002: 18) to all regions of the country? To address these questions, we place the Indian case in the broader context of the existing international and comparative literature on federalism and social policy. At the broadest level, the article combines detached institutional analysis and normative policy prescriptions. 
Four main sections comprise this article. Drawing on the best international literature available, the first section explores the relationship between federalism and health care while making a case for the effective decentralization of health services as a way to improve care delivery. Offering crucial background information about our case, the second section focuses on the historical development of federalism and of health and social policy in India. The third section outlines the challenges and issues facing the contemporary India health care system with a focus on the flaws of the system as far as rural areas and citizens are concerned. The fourth section explains why, paradoxically, health care decentralization in India could reinforce social citizenship and national identity by favoring the inclusion of rural citizens within the public health care system and, more generally, the Indian polity.

\section{Federalism and the Benefits of Decentralization}

Exploring the impact of federalism on the health care system of India is required because governmental institutions are rarely neutral (Banting \& Corbett, 2002: 4-5; Obinger et al, 2005: 20-21; Jordan, 2008: 183). Institutions shape the behavior and decisions of political actors, which directly impact policy development, in health care reform and beyond (Banting \& Corbett, 2002: 4; Obinger et al, 2005: 20-21; see also Immergut, 1992; Lecours 2005; Maioni, 1998; Skocpol, 1992; Steinmo, Thelen \& Longstreth, 1992; Weaver \& Rockman, 1993).

The health care and social policy literatures stress that a number of aspects of a federal system can influence and constrain the public health care system, namely, multiple veto points, interregional tax competition, and regional jurisdictions (Jordan, 2008:166; Obinger et al, 2005: 3-4, 20-22, 31; Banting \& Corbett, 2002: 5; on "veto points" see Immergut 1992). More specifically, the literature presents a significant amount of research grounded in the assumption that federalism and decentralization are inversely related to the growth of the welfare state (Banting \& Corbett, 2002: 5; Obinger et al, 2005: 2, 32). However, as long as the fiscal and institutional incentives are right, federalism and policy decentralization can have positive social policy consequences (Théret, 1999).

In fact, for Govinda Rao and Nirvakir Singh (2005), a decentralized form of government is theoretically better at delivering public goods to citizens for two reasons. First, information about the preferences of constituents is easier to obtain. Arguably, then, local and regional governments that have this information would do a better job of providing such goods. Second, the transmission of information is costly and decentralization can effectively cut transaction costs because the information does not have to be channeled through the center for it to be acted upon. Lastly, policymakers can be held accountable more effectively through a decentralized form of governance by having representatives at the local or state level. Having local-level responsibility would call for a more effective provision of public goods because it can mean a higher chance of re-election. In turn, this situation may increase the level of trust citizens have in the state (Rao \& Singh, 2005: 25-26), which could also improve the sense of national unity and shared citizenship.

Political accountability, however, may be less transparent within a decentralized polity, as "Government decision makers may know exactly what to do to satisfy constituents but still not do it" (Rao and Singh, 2005: 27). Although, decision making individuals will be closer to "the people," local capture by local elites is a pressing problem within India. Decentralization does not guarantee that local leaders will not take advantage of their power. This article defends the necessity of decentralization as a first step to improving rural access to health care. Decentralization is by no means a "cure-all" to the challenges the Indian health care system faces. However, if implemented properly, it has the benefits outlined above.

\section{Federalism and Health Care in India}

In order to understand how present-day India can effectively decentralize its health care system to improve service delivery across the country, a brief historical survey of India's federalism and its welfare state is necessary. It will help explain where it is currently failing. Institutional decentralization in India dates back to British rule, exemplified by the relationship between Indian princely states and the British administration: the states had discretion with respect to internal affairs, although they were ultimately under British control (Rao and Singh, 2005: 42). Late-nineteenth century India, still under British rule, took on a more administrative form of decentralization - that is, states were separated and reorganized "with administrative convenience in mind" (Rao and Singh, 2005: 42). Eventually, the federalism that India represents today saw its beginning in the 1880s. Congress at that time developed a federal structure on "the basis of regional circles, and increasingly on linguistic lines" (Rao \& Singh, 2005: 42). In 1928, the Motilal Nehru Committee drafted a report, stating that an independent India would be parliamentary, bicameral, and federal (Stepan, 2010: 55).

Drafted in 1950, the Indian Constitution includes Article 39, which outlines employee rights to health care, and Article 246, titled "The Seventh Schedule," outlines central- and state-level health care responsibilities. Although these two articles in the Indian Constitution recognized health care as a government responsibility, health care 
was never matched with appropriate political commitment (John, 2010: 17; Reddy et al., 2011: 761).

Today in India, health care responsibilities are theoretically decentralized amongst levels of government, but the system remains excessively centralized. Most rural local bodies are constitutionally responsible for their immediate health care system; however, being under the jurisdiction of the respective states, these local governments lack sufficient policy autonomy and capacity.

In the late 1980s, a panel known as the Sarkaria Commission was appointed to review center-state relations. The commission concluded that the center had been maintaining too much power. The commission recommended greater decentralization of power by allowing states more autonomy (Ray, 1988: 1131; Bagchi, 2003: 26). Ideally, after the recommendations of the Sarkaria Commission and the onset of Indian liberalization in the 1990s (Bagchi, 2003: 21), there should have been greater decentralization in India. In reality, however, the transition towards a more decentralized form of political and fiscal federalism has proven difficult. States are still reliant on the center, and a consequence of the limited powers devolved to the states has been a relative neglect of rural and local bodies of government. It is not surprising that, in 2002, the National Commission to Review the Working of the Constitution reported that centralization is the root cause of India's institutional problems (Review of the Working of the Constitution, 2002: Chapter 9 Articles 175-213).

Decentralization of responsibilities down to the local level and, in particular, engaging constituents at the Panchyati Raj level (PRI) (Note 2), can help create greater accountability in the India health care system. This is because effective and accountable governance and an improved delivery of public services is a by-product of effective decentralization that has been matched with appropriate frontline incentives (Singh, 2008: 1-2, 18-19). A major step towards policy decentralization took place in 1993, with the adoption of the 73rd and 74th amendments to the Indian Constitution. Enacted as a response to previous calls for greater responsibility for local governments, these amendments aimed at increasing the autonomy of municipalities and PRIs in some Indian states (Rothermund, 2008: 43; Singh, 2008: 7). The 73rd and 74th Amendment Acts to the Indian Constitution granted constitutional status to PRIs, which are found at the district, block and village levels, and to local urban municipal bodies, respectively (Johnson, 2003: 170).

In addition to other responsibilities, the amendments gave local bodies the responsibility of 28 development activities (India, National Health System Profile). Some of the health care responsibilities included in the Acts are health and sanitation, family welfare, drinking water, women and child development, the public distribution system and poverty alleviation programs (Constitution of India, Article 243G, "Eleventh Schedule"). These amendments helped local governments gain greater autonomy, and generated hopes for improving the quality and effectiveness of public spending by pushing decision-making of local public goods down to the local level (Bagchi, 2003: 22). By having the public good provider operating closer to citizens, Indian officials were hoping to achieve what a properly decentralized federal system could provide (Bagchi, 2003: 22; Rao \& Singh, 2005: 26).

Since 1993, however, despite the 73rd and 74th amendments, very little autonomy has actually been given to local level governments (Bagchi, 2003: 26; Rothermund, 2008: 43). Essentially, the reforms that should have taken place after the Sarkaria Commission in the 1980s and, then, after the enactment of the 73rd and 74th Amendment Acts, have been occurring slowly because power remains centralized both at the national/federal level and, relative to local bodies, at the state level (Bagchi, 2003: 34, 39; Rothermund, 2008: 43). This slowness has been augmented in the area of fiscal responsibilities, given that local governments have little to no influence over fiscal matters. This is because local governments are largely reliant on their respective state governments to finance their health care needs (National Commission on Macroeconomics and Health, 2005: 70; Bagchi, 2003: 34, 39; Johnson, 2003: 7). To make matters worse, state governments are limited in the funds they can allocate to local governments because, as will be discussed in the next section, they are often disadvantaged too when it comes to fiscal powers (Singh, 2008: 16).

Since the 1980s, decentralization has been at the heart of Indian policy debates. The recommendations of the Sarkaria Commission, the 73rd and 74th Amendment Acts, and the 2002 National Commission to Review the Working of the Constitution illustrate this reality. However, despite these developments, power has not been properly delegated downwards and this has had severe implications on social and health policy. The political centralization of powers has distorted incentives at all levels of government in India, notably in the health care system (Singh, 2008: 16).

\section{Indian Federalism and Health Care Reform Today}

As the discussion above suggests, although local governments have been granted health responsibilities, they have not been allocated the authoritative power and the funds to carry out these responsibilities. We will now 
examine if decentralization can effectively be reformed to deliver appropriate health care to all Indians, and why this could be the first step towards more inclusive citizenship and stronger national unity.

From the beginning, it must be recognized that the Indian health care system is in urgent need of reform. A recent study reports that India's formal health care system reaches only about $50 \%$ of the total population (Economist Intelligence Unit, 2009: 1). In addition to lack of access, India has consistently reported a very low physician to citizen ratio of about 0.6 to 1000 (National Commission on Macroeconomics and Health, 2005: 51). Moreover, India spends only about 4.1 percent of its GDP on public health care, low by most standards. For example, India ranks 134 amongst 182 countries on the Human Development Index (Reddy et al., 2011: 761).Finally, India is excessively reliant on the private health care system (Reddy et al 2011).

In order to address many of the problems the Indian health care system faces, on an irregular basis, the national Ministry of Health and Family Welfare releases a National Health Policy Report. The most recent report, released in 2002, makes policy recommendations for improving the Indian health care system. Amit Sen Gupta (2002: 215) criticizes the report for a number of reasons, including the fact that the central government kept state actors out, an apparent example of the enduring dominance of the centre. In general, when it comes to addressing the needs of PRIs and rural constituents, the 2002 National Health Policy Report underestimates the gravity of their needs. The 2010-2011 Annual Report to the People on Health released by the national Ministry of Health and Family Welfare, makes policy recommendations without a call to action. For example, there is meek encouragement for greater civil society integration and increased public investment. However, the report also vaguely hints at allocating health funding to states based on performance indicators and notes that states must start contributing to primary health care independently. It is inferred that such changes, if enacted, may liken some states as being "left out to dry."

The fact that the 2002 and 2010-2011 report do not directly address rural needs in their policy recommendations is worrying. This is an incentive for more pressure to be placed on policymakers to recognize that rural people are consistently subjected to poorer quality health care, have limited access to the public health care system, and report poorer health on average (D. Singh, 2011: 530, 532). Furthermore, rural regions of India are frequently populated by groups that have been historically marginalized, and those who are likely to live in poverty. In turn, rural regions are often the poorest regions of India. Like in other countries, rural regions "confront a vicious circle of greater social needs and weaker revenue capacity" (Banting \& Corbett, 2002: 20) In order to first reach some sort of equity across rural regions, in India as elsewhere, larger amounts of inter-regional tax/revenue transfers are needed to mitigate capital flight (Banting \& Corbett, 2002).

As mentioned in the previous section, local-level governments continue to face restrictions on their fiscal autonomy because they rely heavily on funding in the form of grants from state-level agencies (Rao and Singh, 2005: 332-333). These grants often come with heavy restrictions (Singh, 2003: 13), and are frequently lost in the inefficiencies of the bureaucracy (Economist Intelligence Unit, 2009: 2; Singh, 2008: 18). Tax powers and expenditure responsibilities of local governments depend on their respective state governments (Rao and Singh, 2005: 332-333, Singh, 2008: 10), because they still remain under state responsibility (Constitution of India, First Schedule). States that finance local governments through their State Finance Commission have devolved limited fiscal power to local governments, largely because these states often fall short on their personal revenue (Singh, 2008: 9). Considering this, Singh (2008: 27) suggests increasing the autonomy of local governments by first strengthening the fiscal capacity of state governments, which would allow them to address local issues "in a less constrained manner."

Regarding the federalism-health policy nexus in general, Banting and Corbett (2002) state, "The balance between common benefits and regional diversity in federations is influenced by two key instruments: the strength of the federal policy framework established for health policy, and the strength of interregional financial transfers" (2002:19). By taking these broad remarks and applying them to India, it is apparent that India's framework for public health policy is weak and that this is further matched with a restrictive interregional fiscal transfer system (National Commission on Macroeconomics and Health, 2005: 71, 79). The politics regarding such interregional fiscal transfer systems, and more generally fiscal redistribution, is related to "the underlying level of support for notions of solidarity and social citizenship" (Banting \& Corbett, 2002: 22). Generally, strong interregional redistribution helps balance a country's commitment to social citizenship with the respect of regional diversity (Banting \& Corbett, 2002: 22). Overall, from a fiscal reform standpoint, streamlining health financing in India (see Bansal 1999 for more on this issue) and improving state fiscal capacity, ergo PRI level fiscal capacity, should provide local governments with more room to pursue their health care priorities and, as a consequence, provide health services consistent with universal social citizenship. 
Shifting the focus from fiscal decentralization to a discussion of the decentralization of health care powers, in general, it can be said that in India, health care responsibilities are, to a certain extent, decentralized (Note 3). This decentralization of health care responsibilities varies from state to state. They vary because states determine their respective health care systems (Sing, 2008:5, 8) and, moreover, after 1993, Panchayati Raj Institutions have been given the bulk of health care responsibilities for their constituents. Health care systems that operate under decentralized power have the most presence in rural areas, such as primary health care centers. These are often run by an underfunded and weak public health care system (Bansal, 1991:124-125; Reddy et al 2011: 760). In India, the private health care system dominates in terms of facilities, skilled professionals and resources, and is mostly concentrated in urban areas (National Commission on Macroeconomic and Health, 2005: 50-51). Although research regarding the private health care system in India is limited in breadth, a survey conducted by the National Commission on Macroeconomics and Health (2005: 51) examined the level of access to private health care facilities rural people have. The survey was conducted in eight districts in the states of Andhra Pradesh, West Bengal, Maharashtra, Kerala, Madhya Pradesh, Rajasthan, Bihar, and Uttar Pradesh. The findings show rural people are significantly neglected in terms of access to health professionals, capital, and resources. First, it was reported at the district level that there were only 0.4 doctors and 0.32 nurses for every 1000 people, which is extremely low by international standards. Second, most private health care facilities, along with two thirds of health care professionals, are located in urban areas. Third, 75 percent of the resources, and 85 percent of the health technology, belong to the urban-centric private sector. Lastly, there were only a total of two emergency obstetric care centers in the eight districts under study; these were inaccessible to many rural women because of distance (National Commission on Macroeconomic and Health, 2005: 51).

Alongside appropriate and fiscally sustainable decentralization, given the facts above, the second policy suggestion would be a move towards public health care or strong incentives "to go rural" within private health. For rural health care needs to be addressed, the central government, along with state governments, need to recognize that the expansion of the health care system is imperative.

If done responsively, decentralization of powers down to the district and local levels may help mitigate the neglected rural population. That is, the jurisdiction over health care should be allocated to local governments, which would improve the chances those rural regions have at receiving attention and higher quality care. Greater decentralization promotes greater rural access to health care by creating demand at the local level. Importantly, devolving power to rural governments would give rural agents greater ability to monitor local governmental officials. As a result, rural agents would be able to articulate their policy needs more effectively. This would then create pull factors that would arguably streamline more public funds to rural areas, and have other spinoff benefits, such as effectively eradicated the problem of absenteeism of health care professionals in local hospitals, a key issue that is often responsible for the poor performance of rural local hospitals (Lewis, 2006:17; Singh, 2008: 2).

Currently, India is making some progress in addressing rural needs via decentralized public health care programs. In 2005, the National Rural Health Mission was implemented and aimed to revamp the public health care system "by increasing funding, integration of vertical health and family welfare programs, employment of female accredited social health activities in every village, decentralized health planning, community involvement in health care, strengthening of rural hospitals, providing united funds to health facilities, and mainstreaming traditional systems of medicine into the public health system." (Reddy et al., 2011: 763) The program covers all of India, focusing on 18 states with poor infrastructure. Although this scheme is centrally funded and vertical in organization, its implementation and execution are performed at the local level. As recorded in 2009, the success rates of this program were high and, as a consequence, its continuation was approved (Gill, 2009: 56; Reddy et al., 2011: 763). Though this innovative program shows high success rates, more recently, scandals within this program have become rampant (Chatterjee, 2012). Such scandals are indicative of the widespread and accepted corruption present in nearly all levels of government in India. As suggested above, decentralization to the local level is simply the first of many steps, one of which is the systematic fight against corruption.

As done under the National Rural Health Mission, decentralizing responsibilities align with creating a stronger health care system that extends to the local level, should help increase accountability, and create a health care system that finally meets the needs of the rural and otherwise marginalized groups. A case study that successfully used such an accountability measure is exemplified in the reforms enacted in the state of Karnataka. In efforts to reform its health care system, decentralization of power was one of the first initiatives put forward by the state. This was done under the guidance of the National Rural Health Mission, which ensured accountability in the delivery of health care, through general monitoring of community participation and ensuring that greater infrastructure capacity was prioritized. In addition to the guidance offered by an external program, the reform 
integrated communities and people into the planning process. Sudarshan and Prashant (2011: 791) argue that such integration in the planning process is necessary if the people will take on monitoring responsibilities in the future. It allows citizens to understand the distinctive nuances in a monitoring role.

The Karnataka case shows how external guidance and participation can create accountability. Kerala is another case study we can examine, because this state has achieved "some of the highest indicators of social development in the developing world" (Chaudhari, 2003: 5). However, despite significant health achievements, Kerala faced a "health crisis" in the 1990s triggered by contagious disease outbreaks, increased numbers of HIV/AIDs cases, the rise of parasitic and infectious diseases, and a decrease in the longevity of its people. These factors ultimately deteriorated Kerala's health care conditions (Elamon et al, 2004: 684). As a result, in 1996, the Keralan government, then under the control of the Marxist Party, launched "The People's Campaign for Decentralized Planning." This program gave local governments 35 to 40 percent of development expenditures (Elamon et al, 2004: 685; Chaudhuri, 2003: 2). By empowering local-level actors, Kerala was hoping to motivate community participation in development programs while improving human welfare.

“The People's Campaign for Decentralized Planning” produced successful results and became known as one of the boldest decentralization experiments ever launched in a developing country (Chaudhuri, 2003: 1). Overall Shubhama Chaudhuri's analysis of data collected from the Graham sabahs (local self-governments at the village level) show that participation, empowerment, and democratic deepening were achieved (Chaudhuri, 2003: 8). Notably, there was a dramatic increase in the participation rates of marginalized people and women in the second year of the campaign (Chaudhuri, 2003: 8). In terms of health care reform, child development services improved significantly through such decentralization (Chaudhuri, 2005).

The Karnataka and Kerala cases show how decentralization of health care system can be an effective way to deliver health care to the rural population of India by maintaining ties to an external government and commitment to community level participation. Such drastic reform initiatives had to be taken in these two states because, as we have established, the Indian public health care system remains weak, overall. It is especially weak when dealing with the rural population, the challenges of which are augmented by a large private health care system. As such, most Indian states need a stronger yet properly decentralized health care system. An adequately funded and regulated yet decentralized public health care system would ultimately mean giving rural local bodies' of all states autonomy and fiscal support, systems of local accountability, and guidance from connections to a larger bureaucratic program/institution that would keep local interest groups in check. This health care system, one that has devolved power downwards, would help human development and welfare in India, and could even strengthen Indian citizenship and national identity.

\section{Federalism, Health Care, Social Citizenship, and National Identity}

In the above examination of the impact of federalism on India's health care policy, we often stress the impact that an improved public health care system would have on the country's large rural population. One other factor is that India is a multi-ethnic federal system featuring much ethnic, linguistic, and religious diversity. In general, there is strong evidence that increased homogeneity calls for a strong central government (Obinger et al., 2005: 14). Conversely, do higher levels of heterogeneity call for greater decentralization, as scholars like Jan Erk (2004) have suggested? And, in the field of health care reform in India, would decentralization reinforce or weaken national identity and citizenship integration?

In order to answer these questions it is important to establish that India's national identity at present comes from a difficult history under British rule; and, that observers long rejected the notion that India could develop a strong, unified national identity, given the cleavages associated with the states of Punjab, Bengal, the North Western provinces, and Madras. For instance, in 1888, John Strachey wrote that, because of the ethnic and religious diversity of its population, "there is not, and never was an India, or even any country of India" (quoted in Stepan et al., 2011: 51). However, Indian scholars such as Rabindranath Tagore vouched for a diverse yet united India, arguing that the concept of "nation" would play no positive role in human development. As he stated, "Neither the colorless vagueness of cosmopolitanism nor the fierce self-idolatry of nation worship is the goal of humanity" (Tagore, cited in Stepan et al., 2011: 52). Mahatma Gandhi, also argued for the inclusion of all religions and languages while supporting the idea that the creation of a multinational and multilingual country would be "India's contribution to peace" (Gandhi, quoted in Stepan et al. 2011: 53).

The ideals Gandhi and Tagore had for India more or less materialized. One way to examine India's societal diversity and national identity today, and the role a stronger, yet more decentralized, health care system could play in further uniting the country, is to turn to India's large rural population, as shown above. Even today, 72.2 percent of India's population lives in rural areas (Officer of the Registrar General and Census Commissioner, 
India). Keeping rural people in mind in the dialogue of developing a stronger national Indian identity, India must balance two social values that Keith Banting and Stan Corbett (2002) have identified in their work on federalism and health care reform. First is a commitment to social citizenship achieved through the delivery of proper public services such as health care to all members of society (2002: 18). Second, in the name of such universal social citizenship, India must ensure that public health and social services reach all rural inhabitants. This situation would have the effect of extending the boundaries of social citizenship in India. This is consistent with the broader, above-mentioned idea that, in a federal system, decentralizing the delivery of public goods like health care can help ensure that the concrete needs of citizens at the local level are being met in a more effective manner.

In championing a more effective health care system through decentralization and allowing local communities to pursue their own health care priorities, India would be balancing the above-mentioned values: social citizenship, on one hand, and the respect for regional diversity, on the other (Banting \& Corbett, 2002). This balance could arguably reinforce citizenship integration at large while creating a stronger sense of national identity, one which includes the Indian state as one that is concerned with the welfare of all members of society. This development would be consistent with the recent literature on national identity and social policy, which stresses the impact of social programs, including health care systems, in state-building as well as the drawing and redrawing of national identities. Overall, as this literature shows, the development of social programs is a key tool in the construction of both social citizenship and national identity (Béland and Lecours, 2008; McEwen, 2006). A striking example of the role of health care in the strengthening of national identity in a fragmented, multinational country is Canada, where universal health care has become a powerful national symbol, despite the fact that public health insurance in that country is operated by the provinces (Banting, 2005; Boychuk, 2008; Brodie, 2002).

Our claim here is that, based on the international evidence available, a stronger yet decentralized public health care system could also increase the level of political identification of all citizens, including rural dwellers, with India as a country diverse yet unified. In order to create a stronger public health care system that could reinforce citizenship inclusion and national identification, decentralization down to the local level is necessary (Bagchi, 2003: 39; Singh, 2008: 2, 14). Most imperatively, this decentralization has to be integrated, accepted, and often led by civil society organizations, which could further strengthen citizenship and identification with the Indian polity.

\section{Conclusion}

India is a highly heterogeneous country in ethnicity, religion, and language. It is also diverse in its demographics, given the presence of a large rural population. India has a long history of ethnic tensions, which in recent years have been muted, and Indians typically support and maintain a strong national "Indian" identity. However, there is room to strengthen this identity while improving the lives of citizens, especially rural inhabitants. As the experiences of Canada and other countries suggest (Béland \& Lecours, 2008), improving social policy and, especially, health care, is a potential way to reinforce citizenship and national identity, even when policy delivery takes a decentralized form. For instance, by ensuring that the health care needs of the rural people are met, India could further strengthen social citizenship and, by the same token, national identity. As argued here, India can potentially do this through two major policy reforms; first greater fiscal decentralization - giving local governments larger budgets and greater autonomy over their finances; second, decentralization by delegating health care responsibilities to the appropriate levels of government and ensures accountability frame works; local level needs, should, therein be better heard.

When we make the case for a health care system that reaches the most neglected people in Indian society, we are arguing for much more than for India to simply meet adequate health care indictors. We are also encouraging Indian officials at all levels of government to show that they are committed to meeting the basic social citizenship rights of its entire people, regardless of geography. A decentralized public health care system helps assess what unique health care needs rural people have. And, this information can be most effectively and cheaply acquired through locally decentralized government bodies, which, in turn, allow the Indian state to ensure that it is suitably committed to social citizenship. This commitment from the Indian state could ultimately develop a greater sense of inclusion amongst rural citizens. Such inclusion could supplement the already strong sense of pride that most Indians have in their country, where all citizens should have access to adequate public health services as a matter of right, regardless of where they live.

\section{Acknowledgements}

The authors thank Angela Kempf, André Lecours, and the reviewers for their comments and suggestions. Daniel 
Béland acknowledges support from the Canada Research Chairs Program.

\section{References}

Aspalter, C. (2003). The State and the Making of the Welfare System in India. Journal of National Development, $3(1), 149-179$.

Bagchi, A. (2003). Rethinking Federalism: Changing Power Relations between the Center and the State. Publius: The Journal of Federalism, 33(4), 21-42.

Balarajan, Y., Selvaraj S., \& Subramanian, S. V. (2011). Health Care and Equity in India: Towards Universal Health Coverage 4. The Lancet, 505-515. http://dx.doi.org/10.1016/S0140-6736(10)61960-5

Bansal, R. D. (1999). Health Financing in India: Priorities, Issues, Inter-State Variations and Challenges. Health and Population Perspectives and Issues, $22(3$ \& 4), 123-132.

Banting, K. G. (2005). Canada: Nation-Building in a Federal Welfare State. In H. Obinger, S. Leibfried, \& F. G. Castles (Eds.), Federalism and the Welfare State: New World and European Experiences (pp. 89-137). Cambridge: Cambridge University Press.

Banting, K. G., \& Corbett, S. (Eds.). (2002). Health Policy and Federalism: A Comparative Perspective on Multi-Level Governance. Kingston and Montreal: School of Policy Studies and McGill-Queen's University Press.

Béland, D., \& Lecours, A. (2008). Nationalism and Social Policy: The Politics of Territorial Solidarity. Oxford: Oxford University Press.

Boychuk, G. W. (2008). National Health Insurance in the United States and Canada: Race, Territory, and the Roots of Difference. Washington, DC: Georgetown University Press.

Brodie, J. (2002). Citizenship and Solidarity: Reflections on the Canadian Way. Citizenship Studies, 6, 377-394. http://dx.doi.org/10.1080/1362102022000041231

Chatterjee, P. (2012). How Free Healthcare Became Mired in Corruption and Murder in a Key Indian State. British Medical Journal, 453, 1-2.

Chaudhuri, S. (2003). The Plasticity of Participation: Evidence from a Participatory Governance Experiment: Working Paper. New York: Institute for Social and Economic Research and Policy (Columbia University).

Chaudhuri, S. (2005). Building local democracy: The People's Campaign for Decentralized Planning in the Indian state of Kerala. EASPR, The World Bank: South Asia Decentralization Series.

Chomitz, K., Setiadi, G., Azwar, A., Ismail, N., \& Widiyarti. (1998). What Do Doctors Want? Developing Incentives for Doctors to Serve in Indonesia's Rural and Remote Areas. Policy Research Working Paper 1888. Washington, DC: World Bank.

De Long, B. (2003). India Since Independence: An Analytic Growth Narrative. In D. Rodrik (Ed.), In Search of Prosperity: Analytic Narratives on Economic Growth. Princeton: Princeton University Press.

Deogaonkar, M. (2004). Socio-economic inequality and its effect on healthcare delivery in India: Inequality and healthcare. Electronic Journal of Sociology.

Economist Intelligence Unit. (2009). Healthcare in India: Rural Development. The Economist, March, 1-2. Retrieved from http://graphics.eiu.com/marketing/pdf/Philips_Healthcare\%20Rural\%20India.pdf

Erk, J. (2003). "Wat We Zelf Doen, Doen We Beter": Belgian Substate Nationalisms, Congruence and Public Policy. Journal of Public Policy, 23, 201-224.

Estrin, S., \& Prevezer, M. (2011). The role of informal institutions in corporate governance: Brazil, Russia, India, and China compared. Asia Pacific Journal of Management, 28, 41-67.

Fisman, R., \& Gatti, R. (2002). Decentralization and Corruption: Evidence Across Countries. Journal of Public Economics, 83, 325-345. Retrieved from http://dx.doi.org/10.1596/1813-9450-2290

Gill, K. (2009). A Primary Evaluation of Service Delivery under the National Rural Health Mission (NRHM): Findings from a Study in Andhra Pradesh, Uttar Pradesh, Bihar and Rajasthan, Working Paper. Planning Commission of India.

Gupta, A. S. (2002). National Health Policy 2002: A Brief Critique. The National Medical Journal of India, 15(5), 215-216. http://dx.doi.org/10.5580/ffa

Hazarika, I. (2010). Medical tourism: its potential impact on the health workforce and health systems in India. 
Health Policy and Planning, 25, 248-251. http://dx.doi.org/10.1093/heapol/czp050

Hindriks, J., Keen, M., \& Muthoo, A. (1990). Corruption, extortion and evasion. The Journal of Public Economics, 74, 395-430.

Holahan, J., Weil, A., \& Wiener, J. (Eds.). (2003). Federalism \& Health Policy. Washington, DC: Urban Institute Press.

Horton, R., \& Das, P. (2011). Indian Health: The Path from Crises to Progress. The Lancet, 377, 181-183. http://dx.doi.org/10.1016/S0140-6736(10)62179-4

Immergut, E. L. (1992). Health Politics: Interest and Institutions in Western Europe. Cambridge: Cambridge University Press.

Jha, S. (2007). Governance in the Gullies: Democratic Responsiveness and Leadership in Delhi's Slums. World Development, 35(2), 230-246. http://dx.doi.org/10.1596/1813-9450-3694

John, T. J. (2010). Is India Ready for an Overhaul in Healthcare? Economic and Political Weekly, 45(20), 14-17.

Johnson, C. (2003). Decentralisation in India: Poverty, Politics and Panchayati Raj. London: Overseas Development Institute. Retrieved from www.indg.in/social-sector/nird/decentralisation_in_india.pdf

Jordan, J. (2008). Federalism and Health Care Cost Containment in Comparative Perspective. Publius: The Journal of Federalism, 39(1), 164-186. http://dx.doi.org/10.1093/publius/pjn022

Lecours, A. (2005) New Institutionalism: Theory and Analysis. Toronto: University of Toronto Press.

Lessman, C., \& Markwardt, G. (2010). One Size Fits All? Decentralization, Corruption, and the Monitoring of Bureaucrats. World Development, 38(4), 631-646.

Lewis, M. (2006). Governance and Corruption in Public Health Care Systems, Working Paper. The Center for Global Development, 78, 1-57.

Maioni, A. (1998). Parting at the Crossroads: The Emergence of Health Insurance in the United States and Canada. Princeton: Princeton University Press.

Marshall, T. H. (1950). Citizenship and Social Class, and Other Essays. Cambridge: Cambridge University Press.

McEwen, N. (2006). Nationalism and the State: Welfare and Identity in Scotland and Quebec. Brussels: Peter Lang.

Mehta, P. B. (2005). Citizenship and Accountability the Case of India. Arusha Conference, New Frontiers of Social Policy. New Delhi: Center for Policy Research in New Delhi, 1-51.

National Commission on Macroeconomics and Health. (2005). Report of the National Commission on Macroeconomics and Health. New Delhi: Ministry of Health and Family Welfare.

Noël, A. (1999). Is Decentralization Conservative? Federalism and the Contemporary Debate on the Canadian Welfare State. In R. A. Young (Ed.), Stretching the Federation: The Art of the State in Canada (pp. 195-219). Kingston: Queen's Institute of Intergovernmental Relations.

Obinger, H., Leibfried, S., \& Castles, F. G. (2005). Federalism and the Welfare State: New World and European Experiences. Cambridge: Cambridge University Press.

Officer of the Registrar General and Census Commissioner, India. Census of India. New Delhi: Government of India (Ministry of Home Affairs). Retrieved from http://www.censusindia.gov.in/Census_Data_2001/India_at_Glance/rural.aspx

Parekh, B. (1991). Nehru and the National Philosophy of India. Economic and Political Weekly, 26(1), 35-48.

Pethe, A. (2012). Unravelling the anatomy of legal corruption in India: Focusing on the 'honest graft' by the politicians. Munich Personal RePEc Archive, 47(21), 55-62.

Rao, M. G., \& Singh, N. (2005). Political Economy of Federalism in India. New Delhi, ND: Oxford University Press.

Ray, A. (1988). The Sarkaria Commission's Perspective: An Appraisal. Economic and Political Weekly, 23(22), 1131-1133.

Reddy, K. S., Patel, V., Jha, P., \& Paul V. K. (2011). Towards Achievement of Universal Health Care in India by 2020: A Call to Action. The Lancet, 377, 760-768. http://dx.doi.org/10.1016/S0140-6736(10)61960-5 
Review of the Working of the Constitution. (2002). Retrieved from http://lawmin.nic.in/ncrwc/finalreport.htm

Rose-Ackerman, S., \& Truex, R. (2012). Corruption and Policy Reform. Working Paper: Yale Law and Economics Research, 444, 1-62.

Rothermund, D. (2008). India: The Rise of an Asian Giant. New Haven, Connecticut: Yale University Press. http://dx.doi.org/10.2307/2118402

Shleifer, A., \& Vishny, R. W. (1993). Corruption. The Quarterly Journal of Economics, 108(9), 599-617.

Singh, D. (2011). Development of Scheduled Castes in India - A Review. Journal of Rural Development, 28(4), 529-542.

Singh, N. (2008). Decentralization and Public Delivery of Health Care Services in India. Health Affairs, 27(4), 1-36. http://dx.doi.org/10.1377/hlthaff.27.4.991

Skocpol, T. (1992). Protecting Soldiers and Mothers: The Political Origins of Social Policy in the United States. Cambridge, MA: Belknap Press.

Steinmo, S., Thelen, K. \& Longstreth, F. (Eds.). (1992). Structuring Politics: Historical Institutionalism in Comparative Analysis. Cambridge: Cambridge University Press.

Stepan, A., Linz, J. J., \& Yadav, Y. (2011). Crafting State-Nations: India and Other Multinational Democracies. Baltimore: The Johns Hopkins University Press.

Sudarshan, H., \& Prashant, N. S. (2011). Good Governance in Health Care: The Karnataka Experience. The Lancet, 377, 790-792. http://dx.doi.org/10.1016/S0140-6736(10)62041-7

Théret, B. (1999). Regionalism and Federalism: A Comparative Analysis of the Regulation of Economic Tensions between Regions by Canadian and American Federal Intergovernmental Transfer Programmes. International Journal of Urban and Regional Research, 23(3), 479-512. http://dx.doi.org/10.1111/1468-2427.00209

Weaver, R. K., \& Rockman, B. A. (Eds.). (1993). Do Institutions Matter? Government Capabilities in the U.S. and Abroad. Washington, DC: Brookings Institution.

Weissert, C. S., \& Scheller, D. (2008). Learning from the States? Federalism and National Health Policy. Public $\begin{array}{llll}\text { Administration } \quad \text { Review, } & \text { 68(Supplement } & \text { December), } & \text { S162-S174. }\end{array}$ http://dx.doi.org/10.1111/j.1540-6210.2008.00986.x

\section{Notes}

Note 1. On the concept of social citizenship, which refers to the allocation of social rights to all the inhabitants of a country through the development of concrete social programs, see Marshall, 1950; see also Béland and Lecours, 2008; Brodie, 2002.

Note 2. The Panchyati Raj is roughly defined as a decentralized rural local government, the functioning of which supports the idea of villages governing themselves.

Note 3. See "Organization of the Health System" for a full description of responsibility decentralization at: http://www.searo.who.int/en/Section313/Section1519_10853.htm 